

AJCS 14(02):299-307 (2020)

ISSN:1835-2707

doi: 10.21475/ajcs.20.14.02.p2312

\title{
Temporal rainfall variability as inductor of the phenology of Brazilian semiarid species
}

\author{
Alberício Pereira de Andrade ${ }^{1}$, Divan Soares da Silva ${ }^{2}$, Riselane de Lucena Alcântara Bruno ${ }^{2}$, Dinnara \\ Layza Souza da Silva ${ }^{3}$, João Luciano de Andrade Melo Junior ${ }^{4}$, André Luiz Rodrigues Magalhães ${ }^{1}$, Luan \\ Danilo Ferreira de Andrade Melo ${ }^{4}$, Ariosvaldo Nunes de Medeiros ${ }^{2}$
}

\author{
${ }^{1}$ Academic Unit of Garanhuns, Federal Rural University of Pernambuco, Brazil \\ ${ }^{2}$ Center of Agricultural Sciences, Federal University of Paraíba, Brazil \\ ${ }^{3}$ Center of Agricultural Sciences, State University of Piauí, Brazil \\ ${ }^{4}$ Center of Agricultural Sciences, Federal University of Alagoas, Brazil
}

*Corresponding author: luciiano.andrade@yahoo.com.br

\begin{abstract}
Usually, in the Brazilian semiarid region where dry and humid periods are well determined, phenological events are mainly affected by seasonal rainfall and availability of water in the soil. The studies in these regions have importance especially to understand the dynamics of dry forests. Thus, the objective of this work was to characterize the phenophases of trees $P$. pyramidalis, $C$. blachetianus, A. pyrifolium and J. mollissima, and their relationship with the temporal distribution of rainfall, which occurs in the form of pulses. Furthermore, the effect of goat grazing was evaluated. The experimental areas presented different caprine stockings, where first had ten and the second five. The third stocking remained without goats during the experimental period. For the phenological follow-up, 50 tree individuals of each species were selected, tagged and monitored weekly, at Experimental Station, in the municipality of São João do Cariri-PB. In order to quantify the phenological events, the percentage of Fournier intensity was used, registering the presence and absence of the phenophases: sprouting, flowering, fruiting and senescence, whose data were related to the water pulses and inter-pulses. The phenological events presented annual patterns, with interannual variations in intensity. We observed that the phenophases occur in synchrony with the temporal distribution of the rainfall pulses in the area of its occurrence. As the dry season progresses, reduction in sprouting, flowering and fruiting occurs when the interpulses of rainfall was intensified. The presence of goats did not influence the phenological development of the species.
\end{abstract}

Keywords: Dry forests; Fournier intensity; Goats; Phenophases; Water pulses and inter-pulses.

Abbreviations: Fl_Fournier intensity.

Introduction

Phenology helps in understanding the dynamics of forest ecosystems and is essential for the ecological and evolutionary study of the tropics. Thus, it is necessary to know the periodicity of vegetative and reproductive events to provide subsidies that aid in the complex dynamics of ecosystems (Braga et al., 2019). Thus, phenological studies are important to evaluate the periods that the plant presents flowers and fruits, as well as other phenophases, and to provide information about the life cycle of these plants, being a crucial tool in the knowledge of the dynamics of these organisms (Paz and Souza et al., 2018).

The Brazilian semiarid region is characterized by a high irregularity of the rainfall distribution in space and time. It has two distinct seasons, the rainy season, corresponding to a short period with rainfall, erratic and of very variable intensity; and the dry season, in general with critical period of prolonged drought, when the Caatinga species express their most striking physiognomy, the deciduous. In these conditions, the plant species present dynamics of growth

and development in consonance with the rainfall events (Lima et al., 2018).

The Caatinga provided a scenario for the evolution and irradiation of unique plant strains that contrast with tropical rainforest humid lineage as the plants in this dry forest have developed exceptional adaptations to cope with a "hostile" environment with prolonged, irregular rains and droughts. Several studies have shown that precipitation controls the phenology of many Caatinga species, although other species may start their phenophases independently of the occurrence of rain (Silva et al., 2018).

In the Caatinga, there are woody species, in which the leaf abscision occurs at the end of the rainy season, while other species maintain their leaves during the dry period, resulting in different tree species over time and in space (Silva et al., 2017). It should also be considered that precipitation events are never uniformly spaced in time, and that the probability of occurrence of these events increases during the dry season. It has also been suggested that dry forests provide goods and services significantly different from those of 
humid forests, requiring different approaches to management and conservation (Brand, 2017).

Typically, rainfall events cause concise pulses of soil water content from infiltration due to the small effective depth of most soils in the region. It should be considered that although precipitation events are never uniformly spaced in time, the probability of occurrence of these events increases during the rainy season (Noy-Meir, 1973).

In view of the complexity of the phenological events in the Brazilian semi-arid regions, the objective of the present study was to characterize the phenophases of Pandanus pyramidalis Balf.f., Croton blachetianus Baill, Aspidosperma pyrifolium Mart. \& Zucc. and Jatropha mollissima (Pohl) Baill, endemic to the Caatinga. These species have multiple uses, and their relationship with the temporal distribution of rain pulses is important. Furthermore, evaluation of the effect of the goat on grazing is carried out as a significant factor.

\section{Results and discussion}

\section{Sprouting (emergence of leaves)}

In the first year of evaluation (2007) different intensities were observed for sprouting in the studied species, in which $P$. pyramidalis presented higher Fournier intensity than the others (Fig 1). The sprouting period of $P$. pyramidalis was occurred between March and July, varying between years, with rapid leaf emission in response to the precipitation pulses, peaked a few days after the rains.

Souza et al. (2014) and Parente et al. (2012) identified that rainfall pulses are sufficient to trigger phenological events in this species. Thus, sprouting of $P$. pyramidalis can be classified as a rapid and intense precipitation-dependent event in sufficient quantity to rehydrate the plant.

In the individuals of $C$. blachetianus, the first rains represented the necessary stimulus to trigger the leaf emission that occurred during the months of February to July, with differences of a few days between the study areas (Figure 1). In 2007, the individuals of $C$. blachetianus re-grew after sporadic rains. In the years 2008, 2010 and 2011, no such behavior was observed, corroborating with the hypothesis that probably the leaf buds of this species enter a state of dormancy.

In contrast to our results, Amorim et al. (2009) observed the absence of dormancy of leaf blossoms in C. blachetianus plants in Brazilian semiarid region. They indicated that the resumption of foliar emission is complex and involves many other factors other than response to water availability. This demonstrates how much still needs to be studied on the phenological patterns of Caatinga species.

The sprouting pattern of $A$. pyrifolium presented continuous during the months of February to July, varying according to the years, beginning just before the rainy season (Fig 1). $A$. pyrifolium initiated the leaf loss from July, remaining without leaves for a long period. Another characteristic of this species that was also noticed in $C$. blachetianus is the response to rain events, waiting for more intense rains to restart the leaf emission.

Amorim et al. (2009), worked with another species of the genus Aspidosperma, and reported that both sprouting and leaf fall presented a continuous pattern, with the number of leaves being reduced in relation to sprouting. Parente et al. (2012) studied the same species and identified that the precipitation interfered with phenological behavior, triggering the sprouting period soon after the first rainfall events, in which $A$. pyrifolium was more persistent in maintaining the leaves with the prolongation of the dry season. The higher leaf persistence of $A$. pyrifolium individuals may be associated with the amount of nitrogen translocated to the new leaves as observed by Castro et al. (2013) when studying the phenology of Aspidosperma spcies.

The species J. mollissima showed sprouting between the months of March and June, reaching the peak intensity of Fournier in April 2010 (Figure 1). The species also responded positively to rainfall, presenting a short period of leaf maintenance, being sensitive to the water deficit. This is corroborating with Fernandes et al. (2013) that associated the formation of new leaves to the rainy season and the leaf fall to dry season.

On the other hand, Neves et al. (2010) studied three species of Jatropha in distinct Caatinga environments and observed continuous phenological behavior of the individuals due to the capacity of water storage in the stem. This characteristic allows the occurrence of phenological events even in the absence of rainfall. Even C. blachetianus and A. pyrifolium, are consumed in the dry season, the presence of goats had no effect on the phenology of the individuals. This disagrees with the reports by Parente et al. (2012) who studied the influence of grazing on the phenology of four species in Caatinga area and verified a reduction in total leaves, fruits and flowers in the grazed pickets.

However, this divergence can be explained by the methodological form, in which the phenological data were analyzed. Parente et al. (2012) studied results obtained through weighted averages of visual observations within a period of two years encompassing longer period of phenological evaluation of the species. They observed that the action of grazing goats in the experimental areas did not interfere in the phenological development of the species.

\section{Leaf senescence}

The recorded senescence period for $P$. pyramidalis varied between May and September, according to the interval between the pulses of precipitation (Fig 2). The phenological behavior was similar to that reported by Souza et al. (2014) and Parente et al. (2012) in study of Caatinga species. P. pyramidalis begins the foliar fall in a concentrated way at the end of the dry season. The tendency of the trees of dry environments, where the plants presented their phenophases was mainly regulated by the precipitation. During the years of 2007 and 2008, we observed that $P$. pyramidalis remained without leaves in a period between beginning of August until the month of January, coinciding with the drought season, when the rain begin to become scarce, and soil moisture causes the plant to stabilize the sprouting and initiate foliar abscission. The sensitivity of $P$. pyramidalis to variations in rainfall can be explained by the fact that this species has a dense stem. So, that the possibilities of water reserves become limited, resulting in greater sensitivity to soil water changes and to the water deficit, as measured by interpulse predominates over the precipitation pulses. According to Nogueira et al. (2013) and Santos et al. (2013), dense wood species are sensitive to 
water stress. They rapidly lose leaves as a way to reduce moisture loss.

Figure 2 showed that foliar abscission in C. blachetianus individuals are occurred more continuously over the years, from February to November, when precipitation interpulse became predominant, causing a reduction in soil water content. The period in which $C$. blachetianus remains without leaves is comprised between July and August, corroborating Amorim et al. (2009), who cited this species as being regular in leaf flow.

Leaf fall in the species $A$. pyrifolium is observed during the months of May to September, being intensified in the most critical period of soil water scarcity, as recorded in the other species (Figure 2). The senescence period of the species Aspidosperma can extend this phenophase until October and present in their constitution, reduced amounts of nutrients, mainly nitrogen and carbon, recruited for the following phenophases of flowering and later fruiting.

The leaf fall pattern of J. mollissima occurred between April and July, remaining without leaves for three months. The intensity of leaf abscission during the years 2010 and 2011 was reduced, probably due to the distribution of rainfall (Figure 2). Amorim et al. (2009) correlated the senescence pattern of J. mollissima with C. blachetianus, classifying them as similar, although the leafless period of $J$. mollissima is between two and three months on average, smaller than that of $C$. blachetianus.

Fernandes et al. (2013), worked with J. curcas, observed a behavior similar to that reported for J. mollissima in the years 2010 and 2011, during the rainy season, when there was a significant reduction in leaf abscission. According to Maes et al. (2009), the leaf abscision of J. mollissima guarantees the efficient use of water in the dry season, as well as in the other Caatinga species, beginning at the end of the rainy season and during the dry season.

\section{Flowering}

In the population of $P$. pyramidalis, the flowering period was recorded between March and June (Figure 3) when the leaves were fully expanded. According to Souza et al. (2014) the duration of flowering of $P$. pyramidalis can occur in the period of six months, varying according to the environmental conditions, corroborating with the results obtained in this study.

Flowering peaks in $P$. pyramidalis individuals were observed in May 2008 and 2010 and April 2011. In 2007, even the evaluation period occurred at the end of the rains, the peak was observed in the month of July. Although shorter than the other phenophases, flowering peaks recorded in individuals of $P$. pyramidalis may represent a strategy to concentrate the presence of seasonal pollinators (Van Schaik et al., 1993). The timing occurrence of reproductive phenophases, especially flowering, is crucial because it influences pollination success and thus the rate of seed production (Talora and Morellato, 2000).

Flowering of $C$. blachetianus was occurred in the months of January to June, with peaks in April (2008), March (2010) and February (2011), coinciding with half of the rainy season (Figure 3). In this study, we observed that the presence of goat grazing did not influence the occurrence of these phenophases, since according to Leal et al. (2003), goats look for young seedlings more than flowers and fruits.
A. pyrifolium showed the highest flowering period among the studied species. The flowering was recorded between February and December, with peaks in March (2008) and February (2010). In 2011, flowering showed a greater uniformity in the distribution of this phenophase (Figure 3 ). However, A. pyrifolium may present a biannual flowering pattern as reported by Amorim et al. (2009).

The flowering pattern recorded for J. mollissima was annual, lasting between February and June, with peaks in March, February and May, for the years 2008, 2010 and 2011, respectively, varying according to the period and duration of the rainy season (Figure 3 ). The performance of climatic variables on flowering and other phenophases of $J$. mollissima is reported by Neves et al. (2010), Jongschaap et al., (2007) and Santos et al. (2005) who observed absence of flowers, fruits, leaf fall and sprouting according to the availability of water in the soil.

As observed by Torres and Galetto (2011) and Lesica and Kittelson (2010), in dry areas, flowering tends to occur in the rainy season. In the Caatinga, Amorim et al. (2009), Parente et al. (2012) and Souza et al. (2014) revealed the tendency of the woody species to bloom in the middle or end of the rainy season.

Amorim et al. (2009) observed that flowering in the species C. blachetianus and J. mollissima occurs along the leaf flow phenophase. Machado et al. (1997) reported that flowering can also be observed even before leaf formation. In order to understand the variability of flowering patterns of species action of climatic factors, genetic and intrinsic factors is vital, which highlights the importance of further studies.

\section{Fruiting}

Fruiting in the individuals of $P$. pyramidalis was observed between the months of May and July, in the middle of the rainy period, with peaks in the months of July $(2007,2008$ and 2010) and May during the year of 2011 (Fig 4). Souza et al. (2014) reported that the fruiting period in P. pyramidalis individuals may extend up to eight months. However, in the evaluated individuals the fruiting period (three months) began in the middle of the rainy season of Caatinga, Brazilian semiarid region.

The fruiting period is directly related to the conditions that influence the success of the dispersion and establishment. The fruiting season in seasonal forests is often related to the type of fruit and the dispersal syndrome. For example, $P$. pyramidalis (which is nut), usually fruit in the middle or end of the rainy season (Schwartz, 2013).

C. blachetianus presented fruiting period in the months of February to July, in the years 2008 and 2010, where the peaks reached $60 \%$ of intensity (Fig 4 ). It is important to emphasize that there was no difference in the areas as the duration of fruiting peaks, indicating that the presence of goats does not influence the fruitful development of the species, until the stocking of up to ten animals.

According to Fig 4, the fruiting period of $A$. pyrifolium comprised of April to September. In the year 2008, a short but well defined fruiting peak was identified different from the following years, where a continuity of the event is observed, in area with ten animals. Area I, presented a slightly superior performance compared to other areas, contrary to what was reported by several authors. The goats 




C. blachetianus

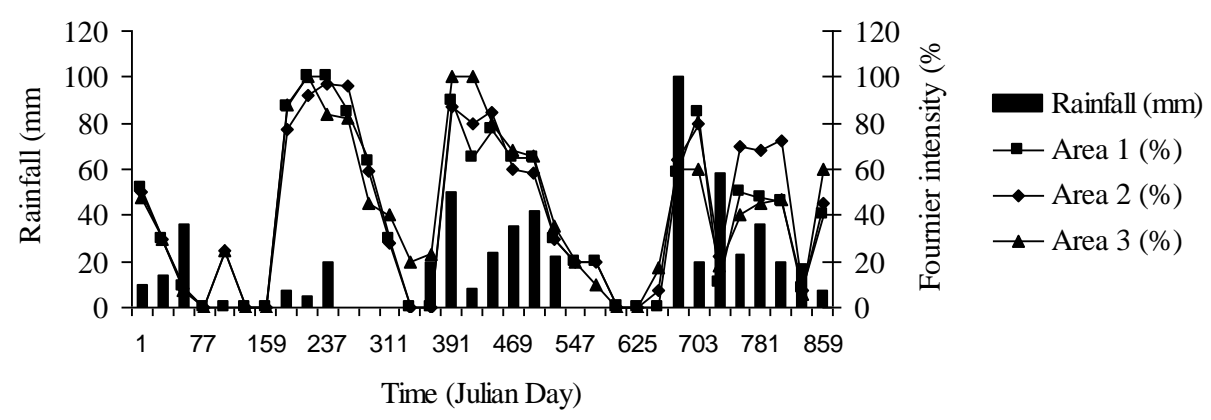

A. pyrifolium



J. mollissima

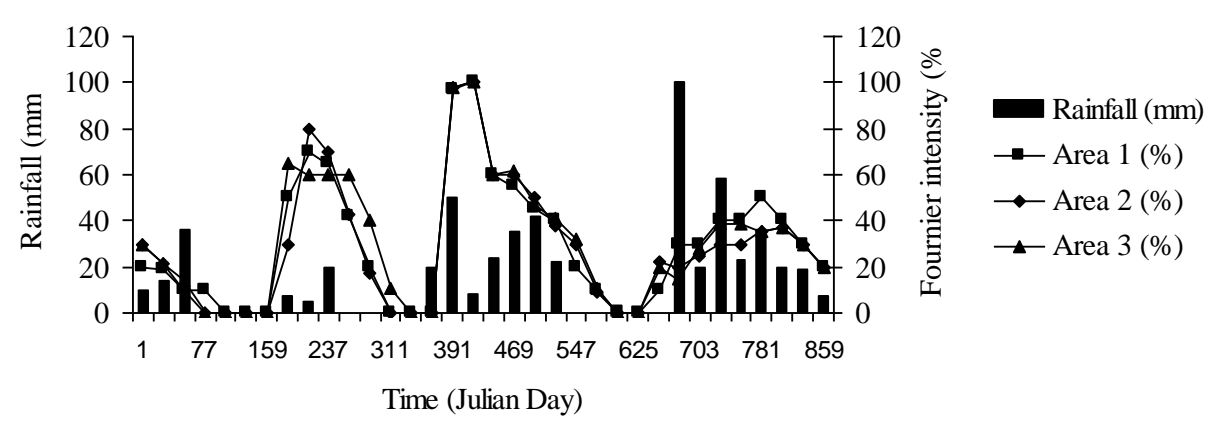

Fig 1. Fl (\%) for sprouting of Caatinga tree species, with different goat stockings from June 2007 to September 2011. 


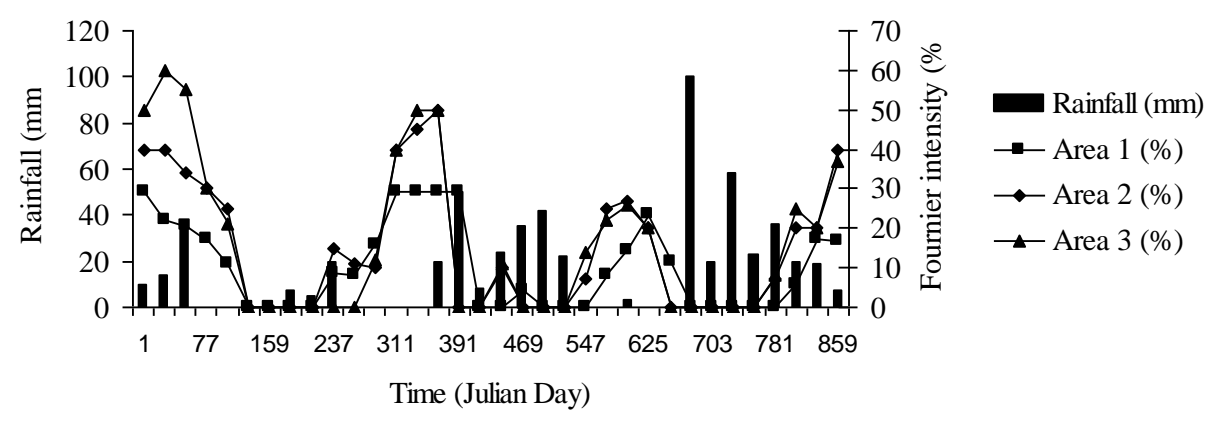

C. blachetianus

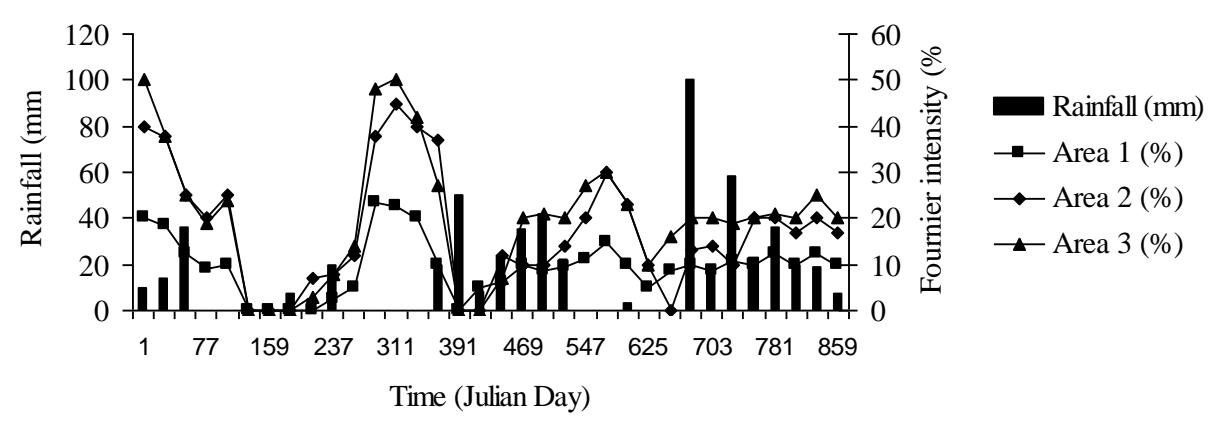

A. pyrifolium

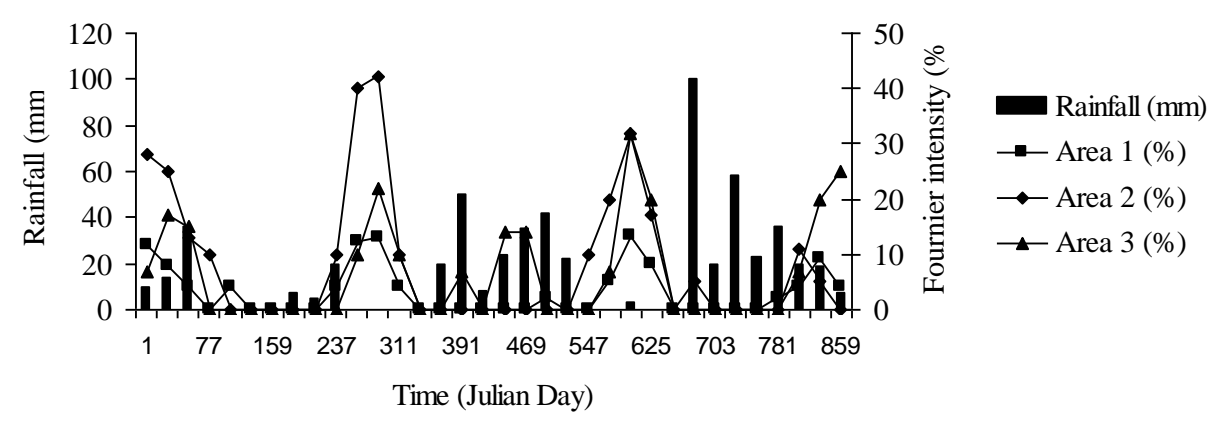

J. mollissima



Fig 2. Fl (\%) for leaf senescence of Caatinga tree species, with different goat stockings from June 2007 to September 2011. 


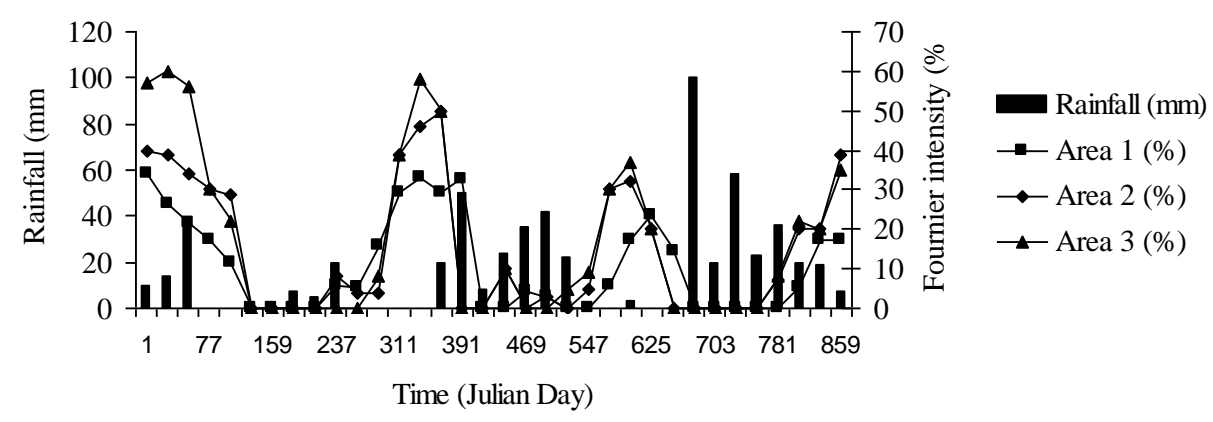

C. blachetianus

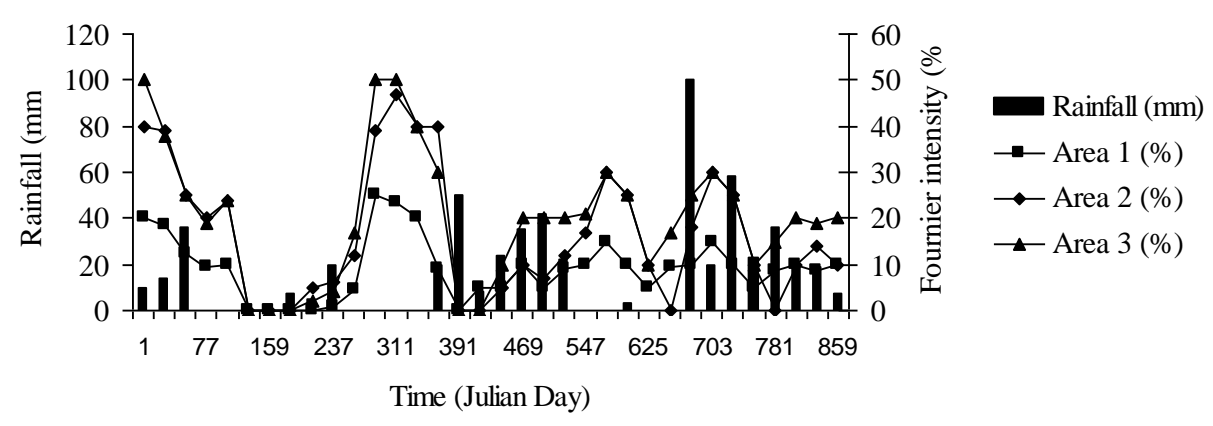

A. pyrifolium



J. mollissima

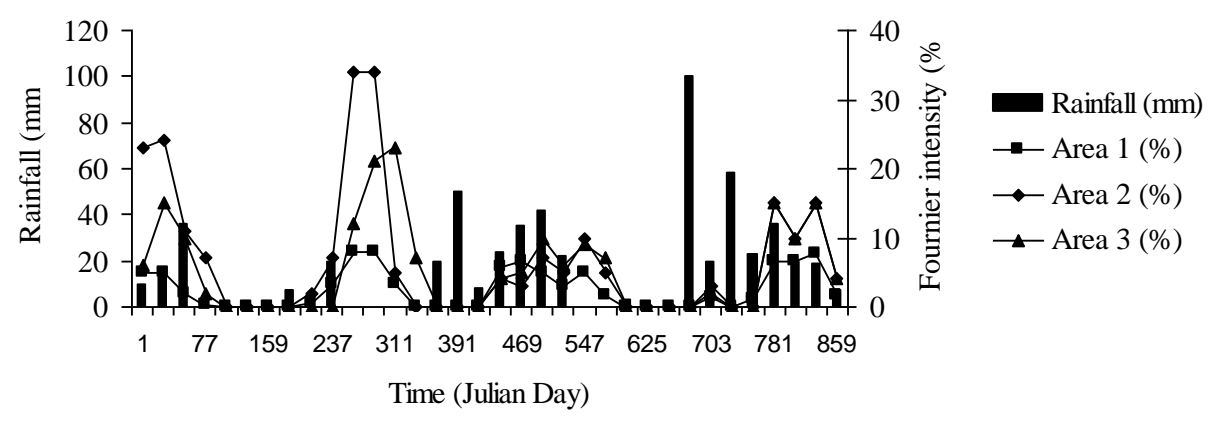

Fig 3. Fl (\%) for flowering of Caatinga tree species, with different goat stockings from June 2007 to September 2011. 


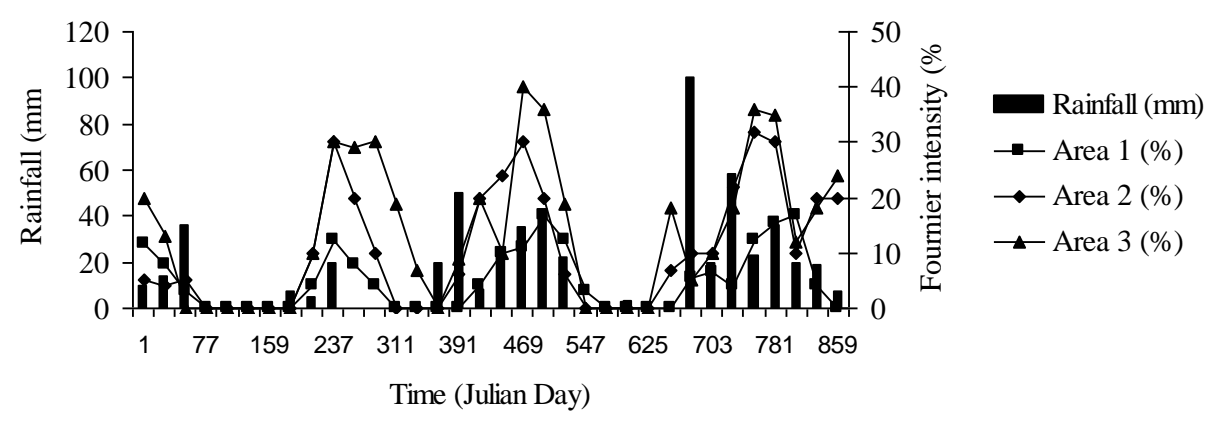

C. blachetianus

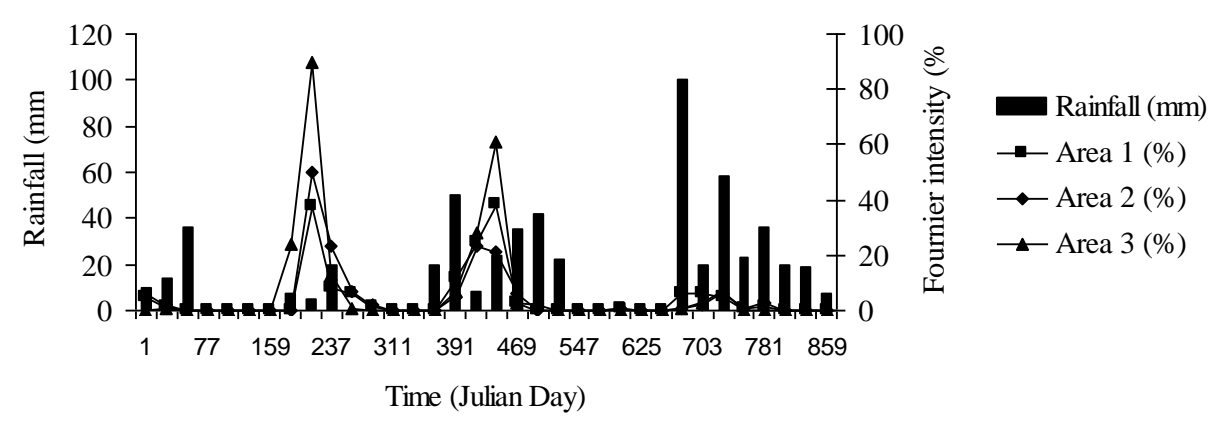

A. pyrifolium

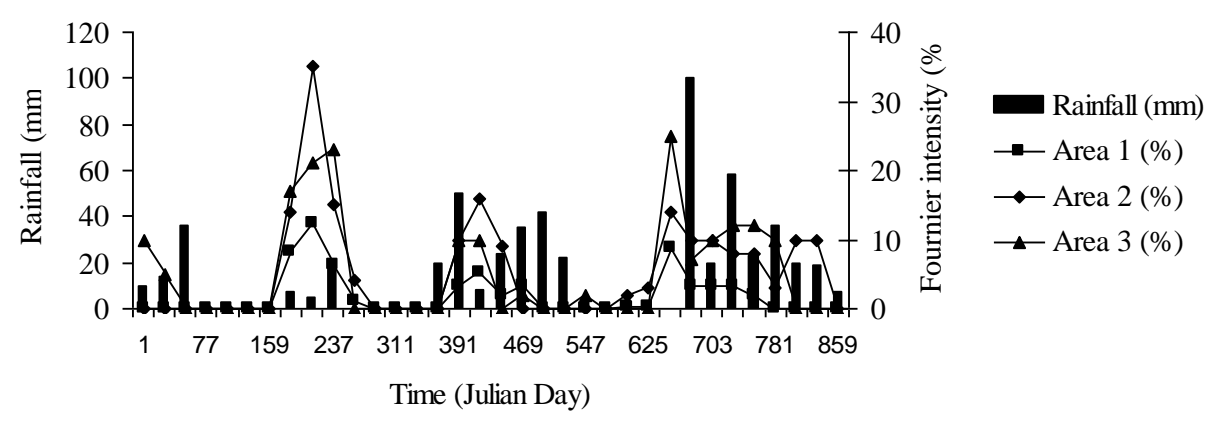

J. mollissima

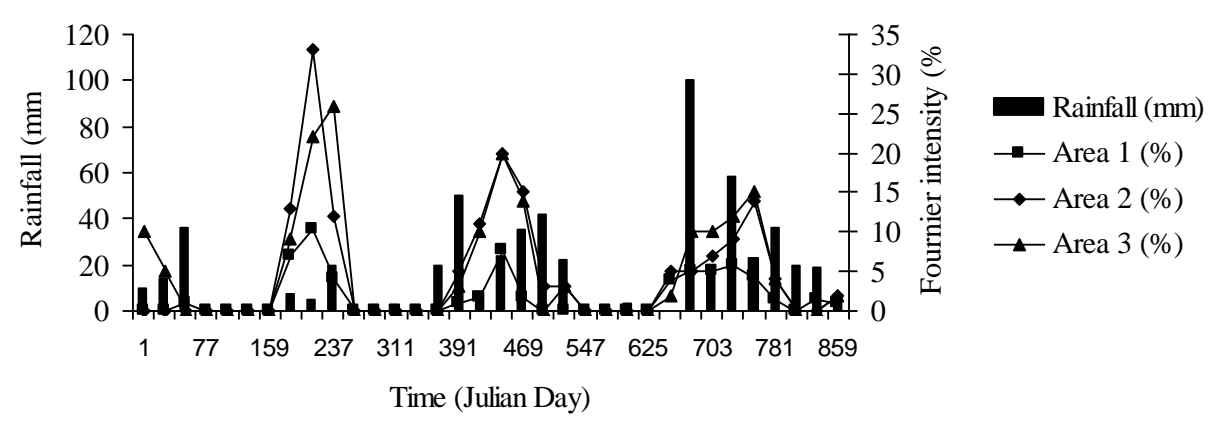

Fig 4. FI (\%) for fruiting of Caatinga tree species, with different goat stockings from June 2007 to September 2011. 
had no influence on the reproductive phenology of this species, among other reasons, to the chemical and anatomical constitution of the fruits.

The occurrence of fruiting during the whole year suggests that environments with absence of dry periods offer little restrictive conditions for the continuous development and maturation of fruits (Bauer et al., 2012). In species such as $A$. pyrifolium, fruiting and dispersal in the rainy season is favored by keeping the fruits more attractive to the dispersers for longer periods, favoring greater zoological dispersion (Belo et al., 2013, Lenza and Klink, 2006; Batalha and Mantovanni, 2000).

J. mollissima presents the fruiting between March and June with well-defined peaks annually (Fig 4). Santos et al. (2010) studied the reproductive phenology of the J. curcas observed a peak of flowering and fruiting during the rainy season, began in April and extending until August, with peaks during the month of June and July, similar to that reported by this work.

The species $P$. pyramidalis, $C$. blachetianus, $A$. pyrifolium and J. mollissima present low dispersion in fruiting events, with average CPD below $40 \%$. This data indicates that the occurrence of the phenophases was occurred for short periods, corroborating with the length of the mean vector. It shows high concentration of flowering at certain times of the year.

The results of the average vector length with concentration around the mean dates high for the years 2007 and 2008, indicates seasonality. Santos et al. (2010) also reported that the vegetative and reproductive events of Caatinga species are mostly seasonal, concentrating their development more intensely in the rainy season.

\section{Materials and methods}

The field study was conducted on Experimental Station of the Federal University of Paraíba, located in the municipality of São João do Cariri, Paraíba State (PB), Brazil, at coordinates -70 23' 30" latitude and -360 31' 59," longitude. The predominant relief in the area is mildly undulated with an altitude of approximately $458 \mathrm{~m}$ in relation to the sea level.

The region is characterized by having a hot and dry climate; according to the Köppen (1948) classification. It is a semiarid type, BSh subtype, with an average annual precipitation of $529 \mathrm{~mm}$, maximum and minimum temperatures of 31 and 17.2 으, respectively, with small variations over the year, and relative air humidity around $77 \%$.

Over the course of the experiment, daily records of precipitation were collected at Climatological Station, in São João do Cariri/PB.

The soils of the study area are mostly shallow, relatively plain to mildly undulate. They are on a crystalline geological structure where the most present types are: Chromic vertic luvisol - tc (Noncalcic brown vertic), Chromic orthic vertisol - vc (Vertisol) and Lithic entisol - rl (Litholic soil). There is also, in small proportions, Eutric Cambisol - cx (Cambisol), Eutric Fluvisol - ru (Alluvial soil), Haplic planosol - sx (Planosol sco) and rocky outcrops with evidence of Lithic entisol (Chaves et al., 2002).

The experimental area comprised of 9.6 ha, divided into three paddocks of 3.2 ha each, with different capacities: Area I (10 goats); area II (five goats); and area III (without the presence of goats). Goats were adult, male and without defined racial pattern, received daily concentrated and mineral supplementation in amount of $200 \mathrm{~g}$ per animal.

\section{Plant materials}

To select individuals of $P$. pyramidalis, $C$. blachetianus, $A$. pyrifolium and J. mollissima, the sampling method was the quadrat (an adaptation of the 'plots' method): ten quadrants (approximately $10 \times 10 \mathrm{~m}$ ) within the experimental area were selected so as to represent the entire Caatinga area of the Experimental Station. The criterion for inclusion of individuals was marked as reference spot in every quadrant and selecting the five closest individuals in the north, south, east and west directions. For each species, 50 trees of similar size, having a trunk with minimum diameter at breast height greater than or equal to $20 \mathrm{~cm}$ were selected. Plants were identified with aluminum plates and non-wovenfabric (TNT) ribbons to be better visualized.

The observations were performed in weekly intervals, recording the presence and absence of the sprouting, leaf senescence, flowering and fruiting phenophases. These phases were defined as follows: sprouting (emergence of leaves) - initially characterized by the presence of leaf primordia, usually of light-green or reddish color, ending when leaves acquired a dark green color; senescence period when the leaves change their color from dark green to brown and the spontaneous leaf abscission starts, forming empty spaces (flaws) at the crown or branches; flowering - period when the tree is at full bloom; fruiting starts from the moment it is possible to visualize the small fruits after the flowers are fertilized and ends with dispersion of the seeds.

\section{Fournier's intensity percentage}

It proposed by Fournier (1974), whereas the values obtained in the field with a five-category ( 0 to 4 ), semi-quantitative interval scale with an interval of $25 \%$ between each category allowed us to estimate the percentage of the phenophase intensity in each individual. Weekly, the intensity values obtained for all individuals of the species were summed and divided by the highest maximum possible value (number of individuals multiplied by four). The result, corresponding to a ratio was then multiplied by 100 to be converted into percentage terms.

\section{Statistical analysis}

The phenological data of intensity of each phenophase (sprouting, senescence, flowering and fruiting) were related to the distribution of rain pulses and through Spearman's correlation coefficient (Zar, 1996), using the number of individuals under each phenophase and the monthly climate data.

\section{Conclusions}

The annual variation in the occurrence of phenological events recorded in the analyzed species is in accordance with the temporal distribution of rainfall. The intensity of the phenophases is associated to the frequency of the precipitation pulses.

The species $P$. pyramidalis is the most sensitive to the variability of precipitation among the species studied. The 
presence of goats under grazing does not influence the phenological development of the species analyzed.

\section{References}

Amorim IL, Sampaio EVSB, Araújo EL (2009) Fenologia de espécies lenhosas da caatinga do Seridó, RN. Rev Árvore. 33(3): 491-499.

Batalha MA, Mantovani W (2000) Some reproductive phenological patterns of cerrado plant species at the Péde-Gigante Reserve (Santa Rita do Passa Quatro, SP, Brazil): a comparison between the herbaceous and woody floras. Rev Bras Biol. 60(1): 129-145.

Bauer D, Goetz MNB, Müller A, Schmitt JL (2012) Fenologia de três espécies de Myrsine L. em floresta secundária semidecídua no sul do Brasil. Rev Árvore. 36(5): 859-868.

Belo RM, Negreiros D, Fernandes GW, Silveira FAO, Ranieri BD, Morellato PC (2013) Fenologia reprodutiva e vegetativa de arbustos endêmicos de campo rupestre na Serra do Cipó, Sudeste do Brasil. Rodriguésia. 64(4): 817828.

Braga AMS, Lima GA, Teodoro MS, Lemos JR (2019) Fenologia de três espécies arbóreas em um trecho de vegetação subcaducifólia no norte do Piauí, Brasil. Biotemas. 32(2): 33-44.

Brand MA (2017) Potencial de uso da biomassa Florestal da Caatinga, sob manejo sustentável, para geração de energia. Rev Ciênc Florest. 27(1): 117-127.

Castro AC, Oliveira DC, Moreira ASFP, Isaias RMS (2013) Synchronism between Aspidosperma macrocarpon (Apocynaceae) resources allocation and the establishment of the gall inducer Pseudophacopteron sp. (Hemiptera: Psylloidea). Rev Biol Trop. 61(4): 1891-1900.

Chaves LHG, Chaves IB, Vasconcelos ACF, Silva APP (2002) Salinidade das águas superficiais e suas relações com a natureza dos solos na Bacia Escola do Açude Namorado e diagnóstico do uso e degradação das terras. Campina Grande, Universidade Federal da Paraíba, $114 \mathrm{p}$.

Fernandes JD, Chaves LHG, Dantas JP, Silva JRP (2013) Fenologia e produção do pinhão-manso cultivado com diferentes fontes de adubação. Rev Ciênc Agron. 44(2): 339-346.

Fournier LA (1974) Un método cuantitativo para la medición de características fenológicas en árboles. Turrialba. 25(4): 422-423.

Jongschaap REE, Corré WJ, Bindraban BS, Brandenburg WA (2007) Claims and facts on Jatropha curcas L. Wageningen, Plant Research International. $42 \mathrm{p}$.

Köppen W (1948) Climatologia; com un estudio de los climas de la tierra. México, Fondo de Cultura Economica, $479 \mathrm{p}$.

Leal IR, Tabarelli M, Silva JMC (2003) Ecologia e conservação da Caatinga. Recife, Universidade Federal de Pernambuco, $804 \mathrm{p}$.

Lenza E, Klink CA (2006) Comportamento fenológico de espécies lenhosas em um cerrado sentido restrito de Brasília, DF. Rev Bras Bot. 29(4): 627-638.

Lesica P, Kittelson PM (2010) Precipitation and temperature are associated with advanced flowering phenology in a semiarid grassland. J. Arid Environ. 74: 1013- 1017.

Lima CF, Bruno RLA, Andrade AP, Pacheco MV, Quirino ZGM, Silva KRG, Belarmino KS (2018) Phenology of Poincianella pyramidalis (Tul.) L. P. Queiroz and its relationship with the temporal distribution of rainfall in the Brazilian semi-arid region. Ci Fl. 28(3): 1035-1048.
Maes WH, Trabucco A, Achten WMJ, Muys B (2009) Climatic growing conditions of Jatropha curcas L. Biomass Bioenergy. 33(10): 1481-1485.

Machado ICS, Barros LM, Sampaio EVSB (1997) Phenology of Caatinga at Serra Talhada, PE, northeastern Brasil. Biotropica. 29(1): 57-68.

Neves EL, Funch LS, Viana BF (2010) Comportamento fenológico de três espécies de Jatropha (Euphorbiaceae) da Caatinga, semiárido do Brasil. Rev Bras Bot. 33(1): 155166.

Nogueira FCB, Filho Pacheco AJS, Gallão MI, Bezerra AME, Filho Medeiros S (2013) Fenologia de Dalbergia cearensis Ducke (Fabaceae) em um fragmento de floresta estacional, no semiárido do nordeste, Brasil. Rev Árvore. 37(4): 657667.

Noy-Meir I (1973) Desert ecosystems: environment and producers. Annu Rev Ecol Evol Syst. 4: 25-41.

Parente HN, Andrade AP, Silva DS, Santos EM, Araújo KD, Parente MOM (2012) Influência do pastejo e da precipitação sobre a fenologia de quatro espécies em área de Caatinga. Rev Árvore. 36(3): 411-421.

Paz WS, Souza JT (2018) Fenologia de espécies vegetais arbóreas em um fragmento de caatinga em Santana do Ipanema, AL, Brasil. Diversitas J. 3(1): 39-44.

Santos RC, Carneiro ACO, Pimenta AS, Castro RVO, Marinho IV, Trugilho PF, Alves ICNA, Castro AFNM (2013) Potencial energético da madeira de espécies oriundas de plano de manejo florestal no estado do Rio Grande do Norte. Rev Ciênc Florest. 23(2): 493-504.

Santos CM, Endres L, Wanderley Filho HCL, Rolim EV, Ferreira VM (2010) Fenologia e crescimento do pinhãomanso cultivado na zona da mata do estado de alagoas, Brasil. Sci Agrar. 11(3): 201-209.

Santos MJ, Machado IC, Lopes AV (2005) Biologia reprodutiva de duas espécies de Jatropha L. (Euphorbiaceae) em Caatinga, Nordeste do Brasil. Rev Bras Bot. 28(2): 361-373.

Schwartz M.D (2013) Phenology: an integrative environmental science. Dordrecht, Springer, $610 \mathrm{p}$.

Silva MC, Souza REVM, Silva BRL, Oliveira VG, Melo FPL (2018) Heterogeneidade de substratos e diversidade de herbáceas na Caatinga sedimentar e cristalina. Revista Brasileira de Meio Ambiente. 3(1): 45-53.

ilva JMC, Leal IR, Tabarelli M (2017) Caatinga: The larguest Tropical Dry Florest Region in South America. Cahm, Springer International Publishing, $506 \mathrm{p}$.

Souza DNN, Camacho RGV, Melo JIM, Rocha LNG, Silva NFS (2014) Estudo fenológico de espécies arbóreas nativas em uma unidade de conservação de caatinga no Estado do Rio Grande do Norte, Brasil. Biotemas. 27(2): 31-42.

Talora DC, Morellato PC (2000) Fenologia de espécies arbóreas em floresta de planície litorânea do sudeste do Brasil. Rev Bras Bot. 23(1): 13-26.

Torres C, Galetto L (2011) Flowering phenology of cooccurring Asteraceae: a matter of climate, ecological interactions, plant attributes or of evolutionary relationships among species. Org Divers Evol. 11(1): 9-19.

Van Schaik CP, Terborgh JW, Wright SJ (1993) The phenology of tropical forests: Adaptive Significance and Consequences for Primary Consumers. Ann Rev Ecol Evol Syst. 24: 353-377.

Zar JH (1996) Biostatistical analysis. New Jersey, PrenticeHall, $662 \mathrm{p}$. 